ANZAAS

\section{Selling public views of science}

Melbourne

THE annual congress of the Australian and New Zealand Association for the Advancement of Science (ANZAAS) has splendidly reformed itself. The usual format was turned on its head at this year's meeting, held at Melbourne's Monash University from 26 to 30 August. The meeting, one week after the Commonwealth government of Prime Minister Bob Hawke had announced its annual budget, provided a timely opportunity for assessing the mood and direction of Australian science and for scientists to make a wider pitch for public support.

At this ANZAAS congress, the 35-odd specialized sections that have dominated the proceedings of ANZAAS for most of its 97-year history as the one organization in Australia and New Zealand attempting to encompass most areas of academic expertise, had disappeared. In their stead, the organizers, led by the energetic congress director, Professor John Swan (chemistry, Monash), built the programme around 129 interdisciplinary symposia focusing on current social issues.

Among the more popular sessions were space science and technology, star wars and new astronomy (in the "hard" category), acquired immune deficiency syndrome (AIDS), sexually transmitted diseases in general and occupational health and safety, schizophrenia and the fluoridation of water supplies and the shape of things to come.

The congress was directed firmly towards a wide general audience, while retaining authority with reputable speakers. Recent congresses have tried, with little success and limited academic respect, to act as meetings for announcing original work. The dominance by social scientists at previous meetings ( 74 per cent of the speakers at the 1984 congress) was corrected; straight scientists this year comprised 51 per cent of the 700 speakers.

To this observer, seasoned by two decades of ANZAAS congresses, the new formula succeeded splendidly. The outreach to the public was a massive improvement. And the scientific community still turned up.

This congress was expertly marketed and attracted large numbers to the Monash campus, despite its remoteness in the flat suburbia of Melbourne. Instead of an all-up registration fee, there was a computerized ticket system handled by a commercial ticket agency. Anyone wishing to attend a half-day session paid \$A8 for entry (students and pensioners \$A5).

The risk was that the organizers had no idea beforehand whether academics and the public would respond, especially given the difficulty of getting to Monash, $20 \mathrm{~km}$ from the city centre. In the event, the 15-17 concurrent sessions were mostly well attended, with 100 -plus audiences, a pleasing increase on the often embarrassingly small sessions of the last traditional congress in Canberra last year. The total number of tickets sold - some 7,000 was estimated to show that at least 3,500 different people attended the formal sessions, a useful improvement on the number of registrations of under 3,000 at congresses over the past decade.

This congress was billed as a "festival of science" and lived up to its ambitious title. A range of events extended well beyond the limitations of the campus-bound symposia. There was, for example, a weeklong special programme for senior highschool students, called "Youth ANZAAS", which drew nearly a thousand young people to a programme launched by the New Zealand folk hero, Sir Edmund Hillary, the president of this year's congress.

The reach of science into the community was extended with a "Community Science and Technology Program". The offer of free tickets to visit some 80 sciencebased institutions throughout Melbourne drew 14,000 takers. There were displays of "everyday science" in the main city square in the week before the congress, and students could follow a "mathematical trail" around the city. One of the most popular events was the "hands-on" science circus, the embryo nucleus of the National Science Centre based at Canberra with a travelling component. All told, ANZAAS activities reached at least 22,000 people directly, nearly eight times as many as at previous meetings. Indirectly, millions of Australians were reached through the extensive media coverage before and during the meeting.

In the present political climate, the significance of the achievement is that it epitomizes a new assertiveness among some of the more politically aware scientists. The 1985 budget dealt relatively kindly with.science; last year's cuts, which so aroused the research community, were at least not repeated. This may be partly the result of the effort by scientific organizations to lift their public game. Thus the Australian Academy of Science has improved the public profile of science through the establishment of its national committee for promoting science and technology. And the largest research institution in Australia, the Commonwealth Scientific and Industrial Organization (CSIRO), which had suffered public opprobrium and financial cuts, directly lobbied key ministers other than their relatively lowly ranked Minister of Science, Mr Barry Jones, after the loss of the technology wing of his portfolio. Mr Jones himself shows a new enthusiasm for promoting fundamental research. At ANZAAS last week, he said that the post-
1984 budget period was "the political Death Valley for Australian science. Scientists were acting like nocturnal animals, being startled by loud noises and retreating under threat, so you cannot see them." After the 1984 budget, Mr Jones had jolted scientists by labelling them as "the wimpiest collection of lobbyists". Now, both he and his opposite number in the Liberal-National Party opposition, $\mathrm{Mr}$ Michael MacKellar, agree that the increased visibility affects budget fortunes. But there is a long way to go.

Through the academy's promotion committee, and again at ANZAAS, plans have been presented for a science and technology information service (for the media, politicians and science educators), a science and government relations bureau, a regular series of polls for gauging and responding to the public opinion of science and scientists, and a book covering Australian science and technology in terms accessible to decision-makers and the public. Some of the running may be made by the Association of Science Communicators of Australia, formed at ANZAAS. Next year, when there will be no ANZAAS congress (the next congress will be in January 1987 at Massey University, New Zealand), the new association plans to hold a national conference instead.

While this ANZAAS congress has been a success, the parent organization struggles along with a low membership and an inadequate budget. Its largest problem is that of keeping alive its monthly journal Search.

Peter Pockley

\section{FDA division to close}

\section{Washington}

The Food and Drug Administration (FDA)'s Drug Chemistry division in downtown Washington, DC, is once again scheduled for closure, apparently as a consequence of pressure within FDA for more resources to be devoted to reviewing New Drug Applications.

The laboratory had one close shave two years ago, when a threat of closure was averted after unfavourable publicity, but this time the deed has been done quietly. Thirty chemists are employed in the division.

Most of the functions of the laboratory, which include developing drug reference standards and new applications for instrumentation, will be transferred to the FDA laboratory in St Louis, Missouri. This will release 20 jobs in Washington to be turned over to reviewing drug applications. But some of the work seems likely to be lost. The division's general methods branch, which has developed new methods of separating stereoisomers, is unlikely to be recreated elsewhere. Two scientists in this division, Irving Wainer and Tom Doyle, received FDA awards for scientific excellence last year. Tim Beardsley 